\title{
Correction to: Discriminative and Criterion Validity of the Autism Spectrum Identity Scale (ASIS)
}

\section{T. A. M. McDonald ${ }^{1,2}$}

Published online: 30 September 2019

○) Springer Science+Business Media, LLC, part of Springer Nature 2019

\section{Correction to: Journal of Autism and Developmental Disorders (2017) 47:3018-3028 https://doi.org/10.1007/s10803-017-3221-2}

The original version of this article contains an error in the Results and Discussion sections and in Table 2.

The corrected text and Table 2 are given below.
Results: Participants' scores were higher for overall stigma and discrimination than those reported by King et al (2007). The pattern of descriptive statistics for the AAQOL was simialr to that reported by Brod et al. (2006).

Discussion: Of note, participants in this study scored approximately 30 points lower than the non-ADHD scores on the AAQOL as reported by Brod and colleagues (2006).
T. A. M. McDonald

t.a.mcdonald@vanderbilt.edu

1 University of Wisconsin, Madison, USA

2 Present Address: Department of Neurology, Vanderbilt University Medical Center, 833 General George Patton Road, Nashville, TN 37221, USA 
Table 2 Descriptive statistics showing the mean, (standard deviation), and Cronbach's alpha (where applicable) SS and AAQOL total and factor scores, the RSE, the FutQOL, loneliness, and self-care for the current study, and the original reports for the SS and AAQOL

\begin{tabular}{|c|c|c|c|c|}
\hline & \multicolumn{2}{|c|}{ Current study } & \multirow{2}{*}{$\begin{array}{l}\text { Original } \\
\text { report }\end{array}$} & \\
\hline & Mean (Std) & $\begin{array}{l}\text { Cronbach's } \\
\text { Alpha }\end{array}$ & & \\
\hline \multicolumn{5}{|l|}{ SS (King et al. 2007) } \\
\hline $\begin{array}{l}\text { Total score } \\
\text { Midpoint }=56\end{array}$ & $\begin{array}{l}81.34 \\
(13.30)\end{array}$ & 0.83 & $\begin{array}{l}62.6 \\
(15.4)\end{array}$ & 0.87 \\
\hline $\begin{array}{l}\text { Discrimination } \\
\text { Midpoint }=26\end{array}$ & $\begin{array}{l}39.48 \\
(8.11)\end{array}$ & 0.78 & $\begin{array}{l}29.1 \\
(9.5)\end{array}$ & 0.87 \\
\hline $\begin{array}{l}\text { Disclosure } \\
\text { Midpoint }=20\end{array}$ & $\begin{array}{l}29.13 \\
(6.58)\end{array}$ & 0.77 & $\begin{array}{l}24.7 \\
(8.0)\end{array}$ & 0.85 \\
\hline $\begin{array}{l}\text { Positive aspects } \\
\text { Midpoint }=4\end{array}$ & $\begin{array}{l}12.73 \\
(2.79)\end{array}$ & 0.43 & $\begin{array}{l}8.8 \\
(2.8)\end{array}$ & 0.64 \\
\hline \multicolumn{5}{|c|}{ AAQOL (Brod et al. 2006) } \\
\hline $\begin{array}{l}\text { Total score } \\
\text { Midpoint }=50\end{array}$ & $\begin{array}{l}58.13 \\
(13.32)\end{array}$ & 0.92 & 60.0 & 0.93 \\
\hline $\begin{array}{l}\text { Life productivity } \\
\text { Midpoint }=50\end{array}$ & $\begin{array}{l}58.13 \\
(16.72)\end{array}$ & 0.88 & 61.9 & 0.88 \\
\hline $\begin{array}{l}\text { Life outlook } \\
\text { Midpoint }=50\end{array}$ & $\begin{array}{l}55.77 \\
(14.89)\end{array}$ & 0.82 & 60.6 & 0.79 \\
\hline $\begin{array}{l}\text { Relationships } \\
\text { Midpoint }=50\end{array}$ & $\begin{array}{l}65.39 \\
(17.98)\end{array}$ & 0.79 & 61.9 & 0.75 \\
\hline $\begin{array}{l}\text { Psychological health } \\
\text { Midpoint }=50\end{array}$ & $\begin{array}{l}54.91 \\
(17.34)\end{array}$ & 0.83 & 53.9 & 0.83 \\
\hline \multicolumn{5}{|c|}{ RSE Scale (Rosenberg 1989) } \\
\hline Midpoint $=3$ & $\begin{array}{l}3.23 \\
(0.83)\end{array}$ & 0.90 & NA & NA \\
\hline \multicolumn{5}{|l|}{ FutQOL } \\
\hline Midpoint $=3$ & $\begin{array}{l}3.39 \\
(0.84)\end{array}$ & 0.78 & NA & NA \\
\hline \multicolumn{5}{|l|}{ Loneliness } \\
\hline Midpoint $=3$ & $\begin{array}{l}2.73 \\
(1.31)\end{array}$ & NA & NA & NA \\
\hline \multicolumn{5}{|l|}{ Self-care } \\
\hline Midpoint $=3$ & $\begin{array}{l}2.97 \\
(1.34)\end{array}$ & NA & NA & NA \\
\hline
\end{tabular}

The distribution of scores in the current study more closely resembled the distribution of scores by those with ADHD than the non-ADHD control group. This is consistent with the widespread reports of decreased quality of life for adults on the autism spectrum (e.g., Howlin and Moss 2012; Taylor \& Seltzer 2011). Further, and consistent with reports of increased stigma (e.g., Shtayermnan, 2009; Tyman, Salor, Saia, et al. 2010), participants in this study scored approximately 20 points higher for overall stigma, and ten points higher for discrimination, than participants with mental illness as reported by King and colleagues (2007).

Publisher's Note Springer Nature remains neutral with regard to jurisdictional claims in published maps and institutional affiliations. 